This article has been published in a revised form in Journal of the Royal Asiatic Society, 28 (2). pp. 355-389. https://doi.org/10.1017/S1356186317000505 This version is published under a Creative Commons CC-BY-NCND. No commercial re-distribution or re-use allowed. Derivative works cannot be distributed. (CThe Royal Page 1 of 45 Asiatic Society 2017

\title{
Revisiting the Bujang Valley: A Southeast Asian entrepôt complex on the maritime trade route
}

Stephen A. Murphy

Curator, Southeast Asia

Asian Civilisations Museum, Singapore

Stephen_Murphy@nhb.gov.sg

Abstract

In the early 1830s and 1840s, a British colonial official by the name of Colonel James Low uncovered evidence for an early culture with Indic traits in a river system known as the Bujang Valley. On the west coast of the Thai-Malay peninsula, the Bujang Valley is today located in the Malaysian state of Kedah. However, it wasn't until just before World War II that excavations took place, conducted by H. G. Quaritch Wales and his wife Dorothy. Their discoveries and subsequent publications led to the first real attempts to explain the origins and extent of this civilisation and its place within the larger South and Southeast Asian world. In the intervening years between Quaritch Wales's excavations and the present day, considerably more research has taken place within the Bujang Valley, though this has not been without controversy. Recently claims and counter-claims regarding the antiquity of Hinduism and Buddhism at the site have arisen in some quarters within Malaysia. It therefore seems pertinent that this material be re-evaluated in light of new scholarship and discoveries as well as the prevailing paradigms of interactions between South and Southeast Asia. This paper presents an updated reading of this material and argues that the Bujang Valley should be seen as a cosmopolitan trading port with substantive evidence for the presence of Hinduism and Buddhism. 
In the early 1830s and 1840s, Colonel James Low, a British colonial officer with the East India Company stationed at Penang, uncovered evidence for an early culture with Indic traits in a river system known as the Bujang Valley. ${ }^{1}$ On the west coast of the Thai-Malay peninsula, the Bujang Valley is today located in the Malaysian state of Kedah (fig. 1). Among the objects that came to light were a large boulder carved with a variety of Indic scripts and a stele inscription bearing a stupa design and the name of a sea captain Buddhagupta (fig. 2). ${ }^{2}$ Some fifty years later, F.W. Irby, another colonial resident, discovered the ruins of a temple on the top of nearby Gunung Jerai peak. This was followed in the 1920s and 1930s by I. H. N. Evans's work in which he compiled an inventory of monuments and artefacts in the area. ${ }^{3}$ However, it wasn't until just before World War II that excavations took place, this time under the direction of H. G. Quaritch Wales and his wife. Their discoveries and subsequent publications led to the first real attempts to explain the origins and extent of this culture and its place within the larger South and Southeast Asian world. ${ }^{4}$

\footnotetext{
${ }^{1}$ James Low, Marong Mahawangsa. The Keddah Annals (Bangkok: Vajiranana National Library, 1908), p. 11.

2 The boulder is known as the Cherok Tokun inscription and is today located within the grounds of the Church of St. Anne in the town of Bukit Mertajam. It has up to seven separate inscriptions upon it and dates to ca. the fifth to sixth century. The Buddhagupta stele was found by Low in 1834 and was sent to the Indian Museum Kolkata were it is still housed today. It too dates to ca. the fifth to sixth century CE. See James Low, 'An account of several inscriptions found in Province Wellesley, on the Peninsula of Malacca', Journal of the Asiatic Society of Bengal, XVII, 2 (1848): 62-6; Michel Jacq-Hergoualc'h, The Malay Peninsula: crossroads of the maritime silk road (100 BC-1300 AD), Victoria Hobson (transl.), (Leiden: Brill 2002), pp. 2136.

${ }^{3}$ Evans was at the time curator of the Perak Museum, Taiping.

${ }^{4}$ Horace G. Quaritch Wales, 'Archaeological researches on ancient Indian colonization in Malaya', Journal of the Malaysian Branch of the Royal Asiatic Society [henceforth JMBRAS], 18, (1940): xiii-85; Dorothy C. Quaritch Wales, \& Horace G. Quaritch Wales, 'Further work on Indian sites in Malaya', JMBRAS XX, 1 (1947): 1-11.
} 
At about the same time as James Low was carrying out his explorations from his posting in Penang, plans were afoot in Singapore to establish a museum, the aim of which was to showcase the region's heritage and culture. ${ }^{5}$ To this end, a library was established in 1845 and by 1849 a museum was added. However, it was not until 1874 that a committee was put together to implement the formation of the Raffles Library and Museum. By 1887, the museum had moved from the town hall into its own building and quickly became the major repository in the region for not only historical and archaeological material from the Malay world, but also zoological and ethnographic collections. It was to this museum, therefore, that Quaritch Wales sent the majority of his finds from his Bujang Valley excavations. With the independence of Singapore in 1965, the material stayed within the museum's collection and to this day it remains part of Singapore's national collection. ${ }^{6}$

In the intervening years between Quaritch Wales's excavations and the present day, considerably more research has taken place both within the Bujang Valley region and across Southeast Asia as a whole. For instance, in 2008 the Centre for Global Archaeological Research at the Universiti Sains Malaysia initiated an archaeological research program in the Bujang Valley led by Professor Mokhtar Saidin. This represents the newest phase of investigations into this complex of sites and it has already produced a number of important discoveries. The focus of its research has been around the area of Sungai Batu, a tributary of the Sungai Merbok. While this area had been noted by scholars in the past, until 2008 no intensive research had been carried out here. As of 2009 - 2010, excavations have unearthed evidence for an iron smelting industry, an ancient brick structure, and another brick structure which appears to be a jetty. ${ }^{7}$ The brick structure (SB1B) is of particular interest, as it appears to be either Buddhist or Hindu. For instance, a

\footnotetext{
${ }^{5}$ Gretchen Liu, One hundred years of the National Museum Singapore 1887-1987 (Singapore: National Museum Singapore, 1987), pp. 16-20.

${ }^{6}$ The museum and library separated in 1960. In 1965 the museum was renamed the National Museum. With the establishment of the National Heritage Board (NHB) in 1993, the museum was once again renamed, this time as the Singapore History Museum. In December 2006 the name reverted back to the National Museum of Singapore.

${ }^{7}$ Saidin et al., 'Issues and problems', p. 20.
} 
Buddhist stone inscription dating to the fifth to sixth century was discovered during its excavation. ${ }^{8}$

However, in May 2016 at a conference and festival on Kedah and the Bujang Valley controversy arose. A number of local Malaysian newspapers quoted Prof. Mokhtar Saidin as allegedly remarking that the Sungai Batu site may have in fact been animist, not Buddhist or Hindu. ${ }^{9}$ This appears to be a highly unusual statement given that there is no evidence or precedent for brick monuments of this type being associated with animistic worship in the Bujang Valley or, to the best of my knowledge, anywhere in Southeast Asia for that matter. He reportedly went on to state that there was also no clear evidence for Buddhist or Hinduism at the Bujang Valley in general and that the excavations that had been carried out in the past during the colonial period could not be considered reliable. ${ }^{10}$ These newspaper reports and the alleged statements they contain from Prof. Saidin were made primarily by a local politician, P. Ramasamy, the Deputy

${ }^{8}$ Zolkurnian Hassan et al. 'Survey and excavation of an ancient monument in Sungai Batu, Bujang Valley, Kedah, Malaysia' in Bujang Valley and early civilisations in Southeast Asia, ed. Stephen Chia and Barbara Watson Andaya (Department of National Heritage, Ministry of Information, Communications and Culture, Malaysia, 2011), pp. 40-41.

${ }^{9}$ The newspaper reports in question are; P. Ramasamy FreeMalaysiatoday.com, May 252016 <http://www.freemalaysiatoday.com/category/opinion/2016/05/25/no-scientific-proof-ofhinduism-buddhism-in-bujang-valley/ > (accessed 16 July 2016); Arnold Loh, thestar.com, May 212016 http://www.thestar.com.my/news/nation/2016/05/21/debate-arises-over-bujang-valleyexperts-disagree-on-religion-practised-at-ruins-older-than-borobodu/ (accessed16 July 2016) and P. Ramasamy FreeMalaysiatoday.com, May 232016 <http://www.freemalaysiatoday.com/category/opinion/2016/05/23/religious-pluralism-alikelihood-in-bujang-valley/> (accessed16 July 2016).

${ }^{10}$ P. Ramasamy FreeMalaysiatoday.com, May 252016 <http://www.freemalaysiatoday.com/category/opinion/2016/05/25/no-scientific-proof-ofhinduism-buddhism-in-bujang-valley/ > (accessed 16 July 2016). 
Chief Minister II of Penang. ${ }^{11}$ Accusations of attempts to cover up the region's Hindu and Buddhist past were rife in the comments sections of many of the online versions of the newspapers. ${ }^{12}$

However upon contacting Prof. Saidin, it became apparent that he had been misquoted. ${ }^{13}$ In a recent email correspondence he states categorically that in his opinion the oldest evidence for Hinduism and Buddhism dates to the fifth century. In terms of one monument SB1B, at Sungai Batu, he suggests animistic influence (discussed in more depth below) but this does not preclude the presence of Buddhism or Hinduism. Nowhere in his published works to date does he state that the Bujang Valley was animist as opposed to Hindu and Buddhist.

This particular incident serves as an example of the conditions archaeologists work under in Malaysia at present. P. Ramasamy's response to Prof. Saidin seems out of proportion and his misquoting of the latter led to a raft of opinions being unleashed in the comments sections about attempts to cover-up Malaysia's pre-Islamic past. Furthermore, this case serves to highlight some of the tensions present in Malaysian society today, particularly amongst ethnically Chinese and Indian citizens. Islamic identity in Malaysia has become increasingly intertwined with politics. Both Malay ethnicity and the Islamic faith have been key factors in shaping the two main political parties in the country: the United Malays National Organization (UMNO) and Pan

\footnotetext{
${ }^{11}$ P. Ramasamy FreeMalaysiatoday.com, May 252016 <http://www.freemalaysiatoday.com/category/opinion/2016/05/25/no-scientific-proof-ofhinduism-buddhism-in-bujang-valley/ > (accessed 16 July 2016).

12 Ibid. and also see, Arnold Loh, thestar.com, May 212016 http://www.thestar.com.my/news/nation/2016/05/21/debate-arises-over-bujang-valley-expertsdisagree-on-religion-practised-at-ruins-older-than-borobodu/ (accessed16 July 2016) and P. Ramasamy FreeMalaysiatoday.com, May 232016 <http://www.freemalaysiatoday.com/category/opinion/2016/05/23/religious-pluralism-alikelihood-in-bujang-valley/> (accessed16 July 2016).

${ }^{13}$ I received an email reply to my queries from Prof. Saidin clarifying his position on $25^{\text {th }}$ July 2016.
} 
Malaysian Islamic Party (PAS).${ }^{14}$ It has been argued that Malaysian Islam has being going through a gradual process of Salafization since the 1970s which has influenced all levels of Malay-Muslim society, including government institutions and Islamic education syllabi. ${ }^{15}$ This and a trend towards "statist Islam," 16 which negates more pluralistic views of both Islam and other religions, has gained more traction under the leadership of Najib Razak who came to power in 2009. As Ahmid Fauzi Abdul Hamid has observed, there has been a "...decline in both bilateral and multilateral interfaith initiatives that engaged both Muslim and non-Muslim religious groups" under Razak's premiership. ${ }^{17}$

These growing tendencies may therefore account for the volatile reactions to Prof. Saidin's seemingly benign statement that one of the monuments may in fact be animist not Buddhist or Hindu. This paper aims to provide a clear and substantive outline of the evidence for Hinduism and Buddhism at the Bujang valley. It will address the issue of the reliability of such evidence as well as the interpretations of it, including their evolution over the past century and a half. In doing so, it is hoped that the paper will provide a balanced overview of the state of scholarship today on this highly important archaeological site.

\section{The temporal and environmental landscapes of the Bujang Valley}

The Bujang Valley spans three rivers, a large estuary, and a bay (fig. 3). ${ }^{18}$ The two main rivers are the Sungai Merbok and the Sungai Muda, with the Sungai Bujang a tributary of the former. These rivers lie at the foothills of Gunang Jerai, a 1300 metre mountain peak, and drain into the Straits of Melaka. The valley covers an area of about $224 \mathrm{~km}^{2}$ and represents the richest

\footnotetext{
${ }^{14}$ Ahmad Fauzi Abdul Hamid, 'The Extensive Salafization of Malaysian Islam', Trends in Southeast Asia no.9, 2016, pp. 9-10, 18-19.

${ }^{15}$ Ibid. pp. 14-17.

${ }^{16}$ Ibid. p.4.

${ }^{17}$ Ibid. pp. 17-18.

${ }^{18}$ The Bujang Valley is also sometimes referred to in the scholarly literature as Lembah Bujang, "Lembah" being the Malay word for "Valley".
} 
archaeological zone in Malaysia. ${ }^{19}$ The archaeological sites cluster into three main groups. The first is the recently discovered Sungai Batu site, named after the river of the same name. The Sungai Batu River is a tributary of the Sungai Merbok. This site appears to be the earliest in the Bujang Valley region. The second is the Sungai Mas cluster based along the Sungai Muda, while the third is the Pengkalan Bujang cluster on the Sungai Bujang River (fig. 4). ${ }^{20}$

Archaeologically, the entire Bujang Valley area has an occupation sequence of approximately 1,100 years (ca. third - fourteenth centuries). From the outset it appears to have functioned primarily as a coastal trading post which, over time, developed to become the most extensive entrepôt complex on the west coast of the Thai-Malay peninsula. Part of the reason for this can be explained by its favourable bay and estuary, but another important factor was the seasonality of the monsoons, which would have required ships to layover for months at a time as they waited for the winds to change direction. From May to October the Southwest Monsoon blows across the India Ocean. Ships leaving from Sri Lanka or South India would be blown eastwards, making landfall somewhere along the Thai-Malay peninsula. From October to December the Northeast Monsoon blows in the opposite direction allowing ships from China to utilise it on their journeys to Southeast Asia and beyond. The Bujang Valley was therefore one of the most natural stop off points on the west coast. From here, ships could moor before continuing their journeys east or west, and goods could be traded and moved across transpeninsular routes to entrepôts on the Gulf of Thailand such as Langkasuka or Tambralinga. Its key location and role in this regard was already recognised in seventh century Sui Dynasty, China. In 607 CE, the Sui Court dispatched a major mission bound for Chitu from Guangzhou. Chitu appears to be a phonetic rendering of

${ }^{19}$ M. N. M. Nawawi et al., 'Application of geophysical methods in archaeology studies in Malaysia - a case study from Lembah Bujang, Kedah, Malaysia', in Bujang Valley and early civilisations in Southeast Asia, ed. Stephen Chia and Barbara Watson Andaya (Department of National Heritage, Ministry of Information, Communications and Culture, Malaysia, 2011), p. 61.

${ }^{20}$ Note that only the third cluster, Pengkalan Bujang, is actually located on the Bujang River, with the term Bujang Valley referring more to the archaeological cultures in this area in a generic sense. 
Kedah, that is, the Bujang Valley. The king of Chitu, who is described in the Sui shu as having hundreds of brahmins at his court in addition to paying reverence to the Buddha, reciprocated and sent two missions to China in 608 and $609 \mathrm{CE}$ respectively. ${ }^{21}$ About seventy years later the Chinese texts refer to the Bujang Valley as Jietu; it is here that the Chinese monk Yijing, after leaving Palembang in South Sumatra, transferred onto a ship to take him to India in approximately $671 \mathrm{CE} .^{22}$ Ninth-century Arab texts also appear to refer to the Bujang Valley, this time as Kalah and Kataha, and again confirm that it was a key port located along the major shipping routes. ${ }^{23}$

The earliest habitation of the valley was based around the Sungai Batu area. Survey and excavations carried out since 2008 by the Centre for Global Archaeological Research, Universiti Sains Malaysia ${ }^{24}$, has mapped 97 mounds, 10 of which were excavated as of $2010 .^{25}$ Two

${ }^{21}$ Geoff Wade, 'Beyond the southern borders: Southeast Asia in Chinese texts to the ninth century', in Lost Kingdoms: Hindu-Buddhist sculpture of early Southeast Asia, ed. John Guy (New York: The Metropolitan Museum of Art, distributed by Yale University Press, New Haven and London, 2014), pp. 29-30.

${ }^{22}$ Ibid., p. 30

${ }^{23}$ G. R. Tibbetts, 'A Study of Arabic texts containing material on South-East Asia', Oriental Translation Fund, n.s., 44 (Leiden: Brill, 1979): 118-28; Jacq-Hergoualc'h, The Malay Peninsula, pp. 195-7.

${ }^{24}$ Research by the Centre for Global Archaeological Research is ongoing and a full discussion of their findings is beyond the scope of this paper. One major English publication has resulted to date however. Otherwise, reports and papers have been in Malay language. See Bujang Valley and early civilisations in Southeast Asia, ed. Stephen Chia and Barbara Watson Andaya (Department of National Heritage, Ministry of Information, Communications and Culture, Malaysia, 2011).

${ }^{25}$ Mokhtar Saidin et al., 'Issues and problems of previous studies in the Bujang Valley and the discovery of Sungai Batu', in Bujang Valley and early civilisations in Southeast Asia, ed. Stephen Chia and Barbara Watson Andaya (Department of National Heritage, Ministry of Information, Communications and Culture, Malaysia, 2011), p. 20. 
structures that have come to light, a possible stupa and a jetty, may possibly date as early as the first to second centuries CE while an iron smelting site has been dated to the third to sixth centuries CE. ${ }^{26}$ From the sixth to eleventh centuries the main centre appears to have been based around Sungai Mas, while from the eleventh to fourteenth centuries it shifts to Pengkalan Bujang (fig. 4). ${ }^{27}$ Explanations as to the cause of this shifting settlement pattern have focused on falling sea levels and changes in the courses of the rivers. As this polity was primarily an entrepôt, access to both the coast and to the highlands via the rivers for sourcing of forest goods for trade was essential to the entrepôt's survival.

Some of the most important advances in recent years in our understanding of the Bujang Valley come from geological and geophysical mapping, which has enabled a greater reconstruction of the palaeoenvironment. ${ }^{28}$ From these studies, Saidin et al. have established that during the first to third centuries CE the areas around Sungai Mas and Sungai Bujang were either still under sea water or were too swampy to be inhabited. Sungai Batu, on the other hand, was far enough inland to function as a viable port (fig. 5). ${ }^{29}$ Jane Allen has also carried out geoarchaeological research in an effort to explain the apparently anomalous locations of the sites ${ }^{30}$ For instance,

${ }^{26}$ Ibid., pp. 19-20.

${ }^{27}$ Nik Hassan Shuhaimi bin Nik Abd. Rahman and Othman bin Mohd Yatim [henceforth Nik Hassan and Othman], Antiquities of Bujang Valley, (Kuala Lumpur: Museum Association of Malaysia, 1990), pp. 90-4.

${ }^{28}$ Saidin et al., 'Issues and problems', pp. 19-20.

${ }^{29}$ Ibid., fig. 1.2.

30 Jane Allen, 'Trade, Transportation and Tributaries: Exchange, Agriculture and Settlement Distribution in Early Historic-Period Kedah, Malaysia'(University of Hawaii, unpublished PhD, 1988); 'Trade and site distribution in early historic period Kedah: Geoarchaeological, historic and locational evidence', in Indo-Pacific prehistory 1990: proceedings of the 14th Congress of the Indo-Pacific Prehistory Association, Yogyakarta, Indonesia, 26 August to 2 September 1990, ed. Peter Bellwood (Canberra: Indo-Pacific Prehistory Association; Jakarta: Asosiasi Prehistorisi Indonesia, Bulletin 10, 1991), pp. 307-19; 'Inland Angkor, Coastal Kedah: Landscapes, subsistence systems and state development in early Southeast Asia', in Indo-Pacific prehistory : 
she points out that today Pengkalan Bujang is located more than $4 \mathrm{~km}$ upstream from the Merbok estuary while Sungai Mas is separated from both the coastline and the Sungai Muda by a floodplain more than $4 \mathrm{~km}$ wide. ${ }^{31}$ This led her to investigate the rate and extent of coastal progradation and the silting up of the rivers in question. Referencing T. T. Khoo's work, she points out that the Sungai Merbok was never actually a large river. ${ }^{32}$ Instead, what is today's estuary is the remains of a large marine embayment or lagoon which has silted up and reached its current level about 600 years ago (fig. 5). These results have had significant implications as to the social and political organisation of the polity that existed in the Bujang Valley throughout the centuries (see below). ${ }^{33}$

the Chiang Mai papers : proceedings of the 15th Congress of the Indo-Pacific Prehistory Association, Chiang Mai, Thailand, 5 to 12 January 1994, ed. Peter Bellwood \& Dianne Tillotson (Canberra : Indo-Pacific Prehistory Association, Australian National University, Bulletin 16, 1997), pp. 79-87; 'In support of trade: Coastal site location and environmental transformation in early historical-period Malaysia and Thailand', in Indo-Pacific prehistory : the Melaka papers, volume 4 : proceedings of the 16th Congress of the Indo-Pacific Prehistory Association, Melaka, Malaysia, 1 to 7 July 1998, ed. Peter Bellwood (Canberra : Indo-Pacific Prehistory Association, 2000), pp. 62-78; 'Historical maps and geoarchaeological evidence for coastal change during the historical period in Kedah and around the Thai-Malay Peninsula', in Bujang Valley and early civilisations in Southeast Asia, ed. Stephen Chia and Barbara Watson Andaya (Department of National Heritage, Ministry of Information, Communications and Culture, Malaysia, 2011), pp. 137-56.

${ }^{31}$ Allen, 'Historical maps', pp. 142-3.

32 T. T. Khoo, 'Geomorphological evolution of the Mebok estuary area and its impact on the early state of Kedah, northwest peninsular Malaysia', Journal of Southeast Asian Earth Sciences, 13, 3-5, (1996): 347-71.

${ }^{33}$ Research into sea level changes and coastal progradation in Southeast Asia continues to redefine the ancient coastlines within the region. See for instance a recent study of the Gulf of Thailand and its implications for the Dvaravati culture of the Chao Phraya Basin by Trongjai Hutangkura, 'Reconsidering the Palaeo-shoreline in the lower central plain of Thailand', in 
Both Saidin et al.'s and Allen's results indicate that the courses of the rivers changed over time and consequently so did the locations of the trade sites. ${ }^{34}$ The rivers and streams became increasingly silted up due to soil erosion caused by over farming on the surrounding hills, and the coastal plain continued to expand outwards. As a result, the trading sites became increasingly landlocked. As the populations at these centres and, correspondingly, agriculture increased, erosion only worsened, making the problem even more severe. ${ }^{35}$ Today Sungai Batu is about $10 \mathrm{~km}$ from the Straits of Melaka and $7 \mathrm{~km}$ from the Merbok estuary, long ago ceasing to be a viable location for maritime trade. The centre therefore moved towards Sungai Mas until the eleventh century, after which Pengkalan Bujang gained supremacy. By the twelfth to thirteenth centuries, Allen estimates that both Sungai Mas and Pengkalan Bujang's access to the sea would have been blocked off. Pengkalan Bujang subsequently ceased to be viable but Sungai Mas recovered, owing to its location on the Sungai Muda River, which was able to break through the build-up of sandbanks and provide direct access to the sea again.

Greater understanding of the variations in sea levels and river courses has therefore aided in understanding causes behind the changing settlement patterns in the Bujang Valley area. It may also, as Allen suggests, explain apparent discrepancies in ancient maps of the region. ${ }^{36}$ For instance, by stripping away the west coastal plain and geographical features that would not have existed in the early first millennium CE, Allen argues that there is a much larger congruence with Ptolemy's first to second century CE map of the region. The site of Kokkonegara may in fact refer to Sungai Mas or Pengkalan Bujang. ${ }^{37}$ Whether this is the case or not, geoarchaeological research is proving more and more essential in our interpretations of the past.

Before Siam: Essays in Art and Archaeology, ed. Nicolas Revire and Stephen A. Murphy (Bangkok: The Siam Society and River Books, 2014), pp. 32-67.

${ }^{34}$ Saidin et al., 'Issues and problems'; Allen, 'Historical maps'.

${ }^{35}$ Allen, 'Historical maps', p. 144.

${ }^{36}$ Ibid., 148-9.

${ }^{37}$ Ibid., 149. 


\section{The Quaritch Wales Excavations}

In the winter of 1935-1936, Quaritch Wales conducted the second expedition of the GreaterIndian Research Committee, the primary focus of which was the Dvaravati moated site of Si Thep in central Thailand. ${ }^{38}$ The aforementioned committee was under the auspices of the Greater India Society founded in Calcutta [Kolkata] in 1926 with the aim of investigating and understanding India's "internationalism" and colonization of Southeast Asia. ${ }^{39}$ It counted among its founding members such luminaries as Rabindranath Tagore and was greatly influenced by the theories of French Sanskrit scholars such as Sylvain Lévi, among others. Quaritch Wales was also a firm proponent of the views on "Indianization" espoused by the Society. Where others endeavoured to find evidence in support of these theories in terms of linguistics and inscriptions, he turned his attention to the archaeological record.

Quaritch Wales had a lifelong association with Southeast Asia, Thailand in particular. He spent over fifty years studying the region - he was still researching in Thailand and publishing as late at 1983 - and he penned no less than fourteen books and countless journal articles. One of his earliest works, Siamese State Ceremonies: their history and function published in 1931, continues to be an invaluable resource and has subsequently been reprinted (1992) and digitized (2005). His book on Dvaravati, published in 1969, is, to this day, the only publication in the English language to provide an overview and analysis of the archaeological and art historical evidence for this culture. ${ }^{40}$ The Making of Greater India, published in 1961, was also another significant publication outlining his theory of the process of Indianization.

\footnotetext{
${ }^{38}$ H.G. Quaritch Wales, 'The Exploration of Sri Deva, an Ancient Indian City in Indochina', Indian Art and Letters, X, 2, (1936), p. 61.

${ }^{39}$ Kwa Chong-Guan, 'Introduction', in Early Southeast Asia viewed from India: An anthology of articles from the Journal of the Greater India Society, ed. Kwa Chong-Guan (New Delhi: Manohar, 2013), pp. xvi-xxxvii.

${ }^{40}$ H.G. Quaritch Wales, Dvāravatī: the earliest kingdom of Siam (6th to 11th century A.D.) (London: Bernard Quaritch Ltd., 1969).
} 
Quaritch Wales, however, was a man of his times and, like many of his contemporaries, his archaeological methods were not of the same standards as today. He appears sometimes too eager to jump to conclusions from his archaeological discoveries ${ }^{41}$ and his interpretations were coloured by his desire to prove his theories of Hindu colonisation. This was very much the case with his approach to the Bujang Valley sites. We must therefore exercise some caution when studying and drawing conclusions from his work. While scholarship over the past fifty years has by and large debunked and disproved his Indianization theories, this should not undermine the value of his contributions to the field. Today's theories see the process he dedicated his life's research to as much more of an adoption and adaptation of Indian concepts and technologies by Southeast Asians over a long period of time. ${ }^{42}$

Since his trip to Si Thep was curtailed by a prolonged rainy season in late 1935, Quaritch Wales availed himself of this opportunity to carry out excavations in January 1936 at the Dvaravati site of Phong Tuek in Kanchanaburi province, west-central Thailand. ${ }^{43}$ When completed, he subsequently carried out his expedition at $\mathrm{Si}$ Thep as planned. On his return from this trip, he approached the Greater-Indian Research Committee about the possibility of carrying out excavations in Malaysia. His rationale was that there was a great lacuna in our knowledge of the region. He stated that this was hampering "progress in the elucidations of the history of South Eastern Asia and of the processes which brought about ancient Indian cultural expansion, the

${ }^{41}$ Wesley Clarke, 'The skeletons of Phong Tuek: Human remains in Dvaravati ritual contexts', in Before Siam: Essays in Art and Archaeology, ed. Nicolas Revire and Stephen A. Murphy (Bangkok: The Siam Society and River Books, 2014), pp. 314-323.

${ }^{42}$ See Stephen A. Murphy and Leedom Lefferts, 'Globalizing Indian Religions and Southeast Asian Localisms: Incentives for the adoption of Buddhism and Brahmanism in $1^{\text {st }}$ Millennium CE Southeast Asia', in The Routledge Handbook of Globalization and Archaeology, ed. T. Hodos (London: Routledge, forthcoming); also see Ian W. Mabbett, 'The "Indianization" of Southeast Asia: reflections on historical sources', Journal of Southeast Asian Studies 8, 2, (1977): 143-61.

${ }^{43}$ For an in depth discussion and analysis of this excavation see Clarke, 'The skeletons of Phong Tuek", pp. 310-29. 
latter being one of the most important civilizing movements in the history of mankind". ${ }^{44}$ With this grand purpose at the forefront of his mind, he set his sights on the Bujang Valley and its monuments, with the express intention of enlightening humanity to the achievements of Indian culture on Southeast Asian soil.

Over a period of fourteen months from 1936-37, Quaritch Wales and his wife surveyed thirtyone sites in the Bujang Valley and of those, excavated up to twenty-three (fig. 3). ${ }^{45}$ Dorothy C. Quaritch Wales carried out further survey and excavation work in 1941 while her husband was involved in the war, most significantly on site 16A where a bronze Buddha image was found in situ. The results of these excavations were published in two volumes of the Journal of the Malaysian Branch of the Royal Asiatic Society and, as previously mentioned, the majority of the excavated material was sent to Singapore. ${ }^{46}$ What follows is a discussion of the most significant material and sites that Quaritch Wales investigated, his interpretations of it, and how he employed these interpretations to fit his theories of Indianziation. ${ }^{47}$

\section{The sites and their excavated material}

Sites 1 and 2

\footnotetext{
${ }^{44}$ Quaritch Wales, 'Archaeological researches', p. vii.

${ }^{45}$ Quaritch Wales numbered his sites numerically, presumably in the order that he surveyed them. With the exception of Michel Jacq-Hergoualc'h, La civilisation to ports-entrepôts du sud Kedah (Malaysia) Ve $V^{e}$ IV siècle, (Paris: Editions L'Harmattan, 1992), pp. 22-31, this numbering system has by and large been retained by researchers who have following after Quaritch Wales. The Muzium Negara (National Museum) in Kuala Lumpur and the Lembah Bujang Archaeological Museum also follow Quaritch Wales’ numbering system. ${ }^{46}$ Quaritch Wales, ‘Archaeological researches', pp. 1-85; Dorothy C. Quaritch Wales, \& Horace G. Quaritch Wales, 'Further work', pp. 1-11.

${ }^{47}$ A complete list of everything Quaritch Wales excavated is published in Quaritch Wales 'Archaeological researches' and his wife Dorothy's 'Further work'. Also see Jacq-Hergoualc'h, La civilisation, for a systematic evaluation of the aforementioned sites and material.
} 
The first site discussed by Quaritch Wales (site 1) is the only one not located within the Bujang Valley proper; it is some $20 \mathrm{~km}$ north of Gunong Jerai peak. His excavations uncovered a laterite foundation which he interpreted as a possible base of a stupa, while a few feet to the south he discovered a platform which may have represented the base of a wooden structure, most likely an assembly hall or monks' residence. ${ }^{48}$ However, of perhaps greater significance was the discovery of an inscribed stone $6.8 \mathrm{~cm}$ in length in the roots of a nearby tree (fig. 6). The inscription turned out to be a common Buddhist Ye Dharmā formula. On the strength of Mr. J. Allan's reading and analysis, Quaritch Wales dated it and the site to the fourth century CE. ${ }^{49}$

These views, however, were challenged by Alastair Lamb who consulted both Prof. F. D. K. Bosch and Dr. J. G. de Casparis, the former assigning an eighth to ninth century date while the latter stated it was clearly ninth century. ${ }^{50}$ As will be shown in discussions below, de Casparis' dating is more plausible.

Site 2, located about 40 metres to the right bank of the Sungai Bujang River, also revealed an inscription, discovered within the site's laterite foundations. The inscription on a rectangular clay tablet, $13 \mathrm{~cm}$ in length (fig. 6), ${ }^{51}$ was once again read by Allan and also Professor Vogel and Dr.

${ }^{48}$ Quaritch Wales, 'Archaeological researches', pp. 6-7.

${ }^{49} \mathrm{Mr}$. J. Allan was at the time keeper of the Department of Coins and Medals at the British Museum. For a more recent discussion on this formula in a Southeast Asian context see Peter Skilling, 'Traces of the Dharma: Preliminary reports on some ye dhammā and ye dharmā inscriptions from Mainland South-East Asia,' Bulletin de l'École française d'Extrême-Orient [henceforth BEFEO], 90-91, (2003-2004): 273-87; Arlo Griffiths, 'Written traces of the Buddhist past: Mantras and Dhāraṇīs in Indonesian inscriptions,' Bulletin of SOAS, 77, 1 (2014), 137-194.

${ }^{50}$ Alastair Lamb, 'A note on a small inscribed stone tablet from Dr. Wales' Kedah site no. 1', Federation Museums Journal [henceforth FMJ], VII (1962): 67-8.

${ }^{51}$ Quaritch Wales, 'Archaeological researches', p. 8. 
N. P. Chakravarti. ${ }^{52}$ It bears three stanzas of a Mahayana Buddhist text known as Questions of Sagaramati which Dr. Chakravarti proposed could date no later than the early sixth century. On this basis Quaritch Wales dated site 2 to this century as well. However, in a recent study, Skilling argues for a seventh to eighth century date, casting doubt on Quaritch Wales' claims. Skilling also noted that this was the only known citation in South or Southeast Asia of this particular text. ${ }^{53}$ However, in 2007 another such inscription was found at temple site 32 in the Sungai Mas area by archaeologists at Universiti Sains Malaysia. ${ }^{54}$

As we shall see in more detail below, the dates proposed by Quaritch Wales were integral to his theory that an early Buddhist phase (ca. $300-550 \mathrm{CE}$ ) was replaced in the mid-sixth century by a Hindu phase brought into the region by Pallava colonists.

Site 4

The discovery of a miniature shrine or reliquary at site 4 added further grist to Quaritch Wales' mill regarding his theory of Pallava colonisation. ${ }^{55}$ This miniature shrine was found amongst boulders on the Sungai Bujang River bank, close to site 4. Made of bronze and measuring $7 \mathrm{~cm}$ in height by $10.5 \mathrm{~cm}$ in length, it has an open metalwork roof with four crouching figures, one on

${ }^{52}$ Dr. N. P. Chakravarti was at the time the Government Epigraphist for India.

53 Peter Skilling, 'Precious deposits: Buddhism seen through inscriptions in early Southeast Asia', in Lost Kingdoms: Hindu-Buddhist sculpture of early Southeast Asia, ed. John Guy (New York: The Metropolitan Museum of Art, distributed by Yale University Press, New Haven and London, 2014), p. 61. See also Peter Skilling 'The Sāgaramati-paripṛcchā Inscriptions from Kedah' (Forthcoming).

54 The inscription has been published in Malay in the proceedings of a seminar by Nasha Rodziadi Khaw, Nik Hassan Shuhaimi Nik Abdul Rahman, Nazarudin Zainun, Mohd Mokhtar Saidin, 'Prasasti Sungai Mas 2: satu tinjauan paleografi', Seminar Penanda Arasan Penyelidikan Arkeologi di UKM, Anjuran Institut Alam dan Tamadun Melayu, 12-13 Julai 2010, Bilik Senat dan Bilik Majlis Bangunan Canselori Universiti Kebangsaan Malaysia, Bangi.

${ }^{55}$ Quaritch Wales, 'Archaeological researches', pp. 11-5. 
each of its corners. However, Quaritch Wales' main interests were the horseshoe-shaped gable windows on either end. These, he noted, closely resemble the roofs on the rock cut Bhima and Ganesa temples at Mahabalipuram in South India. From this he infers that the temple architecture in Bujang must have resembled this style. He proposed this despite uncovering only the foundations of buildings in his excavations. There are reasons to challenge Quaritch Wales's assumptions, not least that the shrine cover was a potentially portable object which could have been brought to Bujang from India. Based on this roof style, he dates the site to the sixth to seventh century. ${ }^{56}$ Again, numerous objections can be raised. For instance, the shrine was not even found at site 4; therefore, the connection between it and the structure is not certain. Furthermore, as the miniature shrine could have been brought from India, we cannot rule out the possibility that it could have been in use for some time before site 4 was constructed.

Site 8

This site, also referred to as Candi Bukit Batu Pahat, lies on the foothills of Gunung Jerai peak (fig. 7). It has revealed some of the clearest evidence for the tradition of foundation deposits in a Southeast Asian context. Quaritch Wales discovered two nine-chambered stone reliquaries in debris outside of the temple, which he attributed to looting. ${ }^{57}$ However, their contents, unlike the ones excavated by Alastair Lamb some twenty years later (discussed below), did not survive (fig 8). He did, however, find two in situ foundation deposits consisting of small silver capsules containing one small sapphire and one small polished pyrope apiece, in recesses at the chief socles of the south and west corners of the vimana. ${ }^{58}$ A bronze trident was also discovered along

\footnotetext{
${ }^{56}$ Ibid., p. 16.

${ }^{57}$ Ibid., pp. 18-21.

${ }^{58}$ A vimana is the central sanctuary of a temple, usually with a spire. The Garbhagrha or innermost sanctum of the temple which contained the cult icon or deity would be housed within this structure.
} 
with a broken snana-droni and segments of a somasutra - to Quaritch Wales, these finds indicated that the temple was Saivite in religious orientation..$^{59}$

Site 10

Quaritch Wales discovered more foundation deposits at site 10; however, these were Buddhist. ${ }^{60}$ At about $60 \mathrm{~cm}$ below floor level he discovered one gold and six silver discs about $3.5 \mathrm{~cm}$ in diameter. Each is inscribed on one side with writing which Dr. Chakravarti stated were names of bodhisattvas. Chakravarti argues on palaeographic grounds that these date to "a little earlier than the VIII century". ${ }^{61}$ Professor Bosch, on the other hand, argues for a second half of the ninth century date but concurs with Chakravarti that the inscriptions name various bodhisattvas.

Owing to the absence of Chinese ceramics at the site, Quaritch Wales concludes that an eighth or ninth century CE date is the most likely.

Site 12

Site 12 provided Quaritch Wales with some of the clearest evidence for trade contact with China in the Tang period. ${ }^{62}$ This came in the shape of two fragmentary Tang bronze mirrors dating from the ninth to tenth centuries. A fragmentary iron dagger with a bronze hilt was also discovered here. Stylistically, Quaritch Wales sees parallels between it and another dagger worn by the buffalo demon on the Mahisasura Mandapam relief at Mahabalipuram, another element in his Pallava colonisation theory. He also points out this story is represented on the reliefs at Borobodur.

Sites 13 and 14

${ }^{59} \mathrm{~A}$ snana-droni is a pedestal within which the linga is placed, while the somasutra is the channel for receiving the liquids with which a linga has been bathed.

${ }^{60}$ Ibid., pp. $22-4$.

${ }^{61}$ Ibid., p. 23.

${ }^{62}$ Ibid., p. 26. 
Both sites 13 and 14 had reliquary deposits contained in earthenware jars. At site 13, a jar was placed at each of the four corners of the brick sanctuary. These jars contained mollusc shells and glass beads. ${ }^{63}$ At site 14 , only two earthenware jars of a similar design to those at site 13 were found. They contained two silver coins of the Abbisid Caliph al-Mutawakil (847-861 CE), one of them, a half-dirham, bears a date of 234 A.H. $(848 \mathrm{CE}) .{ }^{64}$ Also found inside was an unreadable silver inscription which appears to be written in Pali, beads and a piece of polished amethystine quartz. Quaritch Wales dates both sites to the eighth to ninth centuries.

Site 16

Along with sites 8,10, 13 and 14, Quaritch Wales found further evidence for the tradition of foundation deposits at site $16 .{ }^{65}$ Here the deposit was contained within a bronze bowl about 12 $\mathrm{cm}$ in diameter and $7 \mathrm{~cm}$ in height. It was found in a chamber located beside the entrance to the sanctuary, about $65 \mathrm{~cm}$ from its base. To make room, one laterite block was left out, leaving a cavity for the reliquary. The contents consisted of miniature animals and weapons, and gems. Quaritch Wales proposed that these were meant to represent the attributes of a bodhisattva, possibly of tantric persuasion. However, Jacq-Hergoualc'h points out that architecturally the site is more likely to be Brahmanical and therefore the deities worshipped here should be as well. ${ }^{66}$

The animals consisted of a gold lion, a silver bull, a copper horse, and a fourth animal which appears to be an elephant. The weapons were a bow with two arrows, a sword, a dagger, a noose, a staff or spear, a shield, and a drum. The gems consisted of amethystine quartz, a polished amethyst, a sapphire, a pearl, and two yellow glass octahedrons most likely made of Arab glass. Also found were a number of bronze objects including a bell, most likely for use in temple ritual, an aureole which presumably belonged to a sculpture of a deity which no longer survives, and

\footnotetext{
${ }^{63}$ Ibid., pp. 29-30.

${ }^{64}$ Ibid., p. 32.

${ }^{65}$ Ibid., pp. 35-6.

${ }^{66}$ Jacq-Hergoualc'h, La civilisation, pp. 73-4.
} 
two bronze lamps. An iron ring $8 \mathrm{~cm}$ in diameter was also discovered. Quaritch Wales dated the site to the ninth to tenth centuries.

Site $16 \mathrm{~A}$

Perhaps the most important discovery ever made at Pengkalan Bujang was not by H.G. Quaritch Wales, but by his wife, Dorothy, who excavated site 16A in 1941 while her husband was involved in the war. At this site, located about 15 metres from site 16, she found an in situ bronze Buddha image just over $20 \mathrm{~cm}$ in height (fig. 9). Its Gupta characteristics led her to assign it a fifth century date. However, as shall be seen below, this date has been challenged by some scholars. ${ }^{67}$

Site 18

While sites such as 16A brought to the fore links with India, and the discovery of Tang mirrors at site 12 reflects contact with China, the discovery of a fragmentary glass vase at site 18 provided Quaritch Wales with evidence for trade with the Middle East, most likely Syria. Due to the style of architecture and ceramics found at the site (Sung porcelain), he dates Site 18 to the eleventh to twelfth century. ${ }^{68}$

Sites 19, 20-23

Quaritch Wales also investigated these sites and found that Sung dynasty ceramics were common. He dates them to the eleventh to twelfth centuries. ${ }^{69}$

Quaritch Wales's excavations focused primarily on the sites strung along the Bujang River. His analysis of the data was framed within his hypothesis that there were four waves of Indian

${ }^{67}$ Quaritch Wales, 'Further work', pp. 7-8.

${ }^{68}$ Quaritch Wales, ‘Archaeological researches', pp. 37-9.

${ }^{69}$ Ibid. pp. 39-40. 
cultural expansion. This theory had been published in 1936, the same year as his excavations in Kedah. ${ }^{70}$ For him, the Bujang Valley became Indianized during his proposed second wave (300$550 \mathrm{CE}$ ) when the prevailing religion was Buddhism. However, the third wave (550-750 CE) brought the arrival of the Hindu Pallava colonists, while the fourth wave (750-900 CE) was still from south India, but with influences from Pala in the north. ${ }^{71}$ Throughout, he emphasised the apparent connections with southern India, from the style of the bronze casket found at site 16 to the dagger hilt at site 12 . He sees connections in as much of the material as possible while at the same time is at great pain to stress the dissimilarity of what he had found with artefacts found in Java.

Quaritch Wales's explorations opened up a new chapter in our understanding of not just the archaeology of the Thai-Malay peninsula, but also the nature of trade and contact between Southeast Asia, the Middle East, India, and China. He drew attention to the importance of the sites in the Bujang Valley and paved the way for further research in the area. However, his contentions and interpretations were almost immediately challenged by scholarship from as early as the 1950s onwards. As it shall be discussed below, while many of Quaritch Wales's theories began to be overturned by later scholarship, no doubt was ever cast by these studies on the presence of Buddhism and Hinduism in the Bujang Valley in the first millennium.

\section{Research on the Bujang Valley from the 1950s to the present}

Research resumed at the Bujang Valley in 1955-56, initially by faculty from the University of Malaya, and then again in December 1957 and April 1958 under the auspices of the University of Malaya Archaeological Society. The aim was to revisit and build upon Quaritch Wales's excavations. ${ }^{72}$ Limited excavations took place in the 1955-56 seasons while the 1958 expedition

\footnotetext{
${ }^{70}$ Quaritch Wales, 'The Exploration of Sri Deva', pp. 90-6.

${ }^{71}$ Quaritch Wales, ‘Archaeological researches', pp. 67-74.

72 December - January 1955-56 by Michael Sullivan and July 1956 by K. G. Tregonning and P. F. de Jong. See Michael Sullivan, 'Excavations in Kedah and Province Wellesley, 1957',
} 
focused particularly on site 8, although it did revisit, to a limited extent, sites 7, 18, 26 and 28. Site 8 was completely excavated and subsequently reconstructed by Alastair Lamb between 1958-59. ${ }^{73}$ He carried out further survey and excavation work at Pengkalan Bujang in 1961 and paid a visit to the then Raffles Museum, Singapore, to examine Quaritch Wales's excavated material. $^{74}$

Lamb's research led to the first major challenge of Quaritch Wales's interpretations, particularly in terms of dating and the extent of Pallava influence. More detailed analysis of the Chinese ceramics found at site 8 , for instance, indicated that they date to no earlier than the eleventh century, not the eighth to ninth, as Quaritch Wales had suggested. ${ }^{75}$ The miniature shrine roof that Quaritch Wales discovered at site 4 was dated to the sixth to seventh centuries through comparison with Mahabalipuram. It was also questioned by Lamb, who pointed out that the waggon-roof shape is found throughout India. ${ }^{76}$ Furthermore, comparisons with an incense burner from the Sambas hoard suggests a date of eighth to tenth centuries, thus illustrating that the shrine lid may not be as similar to the Mahabalipuram examples as Quaritch Wales' suggested. ${ }^{77}$ Lamb's observations undermine both Quaritch Wales's dating and assertions of Pallava influence.

In a similar vein, Lamb also proposed possible Javanese influence, particularly in the ninechambered reliquaries found at site $8{ }^{78}$ However, Stanley O’Connor and Anna Ślączka have both pointed out that there has been plenty of Indian textual evidence to indicate its origins are in

JMBRAS, XXXI, 1, (1958): 191-2; Alastair Lamb, 'Recent archaeological work in Kedah', JMBRAS, XXXII, 1 (1959): 214.

${ }^{73}$ Alastair Lamb, 'Report on the excavation and reconstruction of Chandi Bukit Batu Pahat, central Kedah', FMJ, V (1960): x-108.

${ }^{74}$ Alastair Lamb, 'Research at Pengkalan Bujang: A preliminary report', FMJ, VI (1961): 21-37.

75 Lamb, 'Report on the excavation', p. 11.

${ }^{76}$ Ibid, p. 9.

${ }^{77}$ K. A. Nilakanta Sastri, 'A note on the Sambas finds', JMBRAS, XXII, 4, (1949):18.

${ }^{78}$ Lamb, 'Report on the excavation', pp. 8, 74-90. 
fact from the sub-continent. ${ }^{79}$ O'Connor's review of the evidence not only in Bujang and Java, but also in southern Thailand and the Cham regions of Vietnam, shows that this tradition spread into the various cultures of Southeast Asia. Ślączka, too, argues that Southeast Asians adopted this consecration ritual but cautions that the meanings and significance of these ceremonies may have been altered and adapted to local beliefs and sensitivities. ${ }^{80}$ Either way, there is no reason to think that the tradition found at site 8 in Bujang came from Java as Lamb suggested.

Quaritch Wales had found two reliquaries from site 8 in his excavations. Lamb, during the course of his, found six more, bringing the total to eight. They were all found within sanctuary walls at floor level, one in each of the four corners and one at each midpoint of the sanctuary walls. ${ }^{81}$ The reliquaries were made from the same stone as the blocks of the temple, which Quaritch Wales referred to as quartzite but Lamb points out is actually granite (fig. 8). The central depression of each reliquary contained a gold, silver, or copper foil, while the other depressions contained semi-precious stones such as ruby or rock crystal and/or other substances. ${ }^{82}$ The objects in the central depressions were shaped as animals (a turtle and a bull), linga, female figurines, and lotus flowers which confirms the Saivite religious affiliation of the temple (fig. 10). This was further confirmed by F. E. Treloar's chemical analysis of the objects with some, such as the linga, showing high mercury content; mercury was considered the seed of Siva. $^{83}$

${ }^{79}$ Stanley O' Connor, 'Ritual deposit boxes in Southeast Asian sanctuaries', Artibus Asiae, XXVIII, 1 (1966), pp. 53-60; Anna A. Ślączka, Temple consecration rituals in ancient India : text and archaeology (Leiden ; Boston : Brill, 2007); Anna A. Ślączka, 'Golden bulls and tortoises: temple consecration in Southeast Asia”, Orientations, 45, 3 (2014): 71-5. 80 Ślączka, 'Golden bulls', p. 75.

${ }^{81}$ Lamb, 'Report on the excavation', pp. 74-5.

${ }^{82}$ Ibid., pp. 79-90.

${ }^{83}$ F. E. Treloar, 'Chemical analysis of some metal objects from Chandi Bukit Batu Pahat, Kedah: Suggested origins and date', JMBRAS, XLI, 1 (1968), pp. 193-8; F. E. Treloar, 'The use of mercury in metal ritual objects as a symbol of Siva', Artibus Asiae, XXXIV, (1972): 232-40. 
Lamb also proposed a new dating sequence for the Bujang Valley. The most significant revision was to Pengkalan Bujang which, based on his reassessment of ceramics, he dated between the eleventh to fourteenth centuries. This ruled out any possibility of Pallava influence in this area of the Bujang Valley. ${ }^{84}$ For Lamb, the first phase of occupation spanned the fourth to fifth centuries and took place on the south bank of the Muda River (viz. Sungai Mas) and was Buddhist. This conclusion was based on the three inscriptions known at that time: the Buddhagupta Stele, the Bukit Meriam inscription, and the stone tablet found by Quatritch Wales at site 1. Lamb's second period was called the Srivijayan phase with the sites in this group located in the upper reaches of the Bujang river, essentially from site 16 upwards. The main dates for these sites range from the seventh to ninth centuries. Lamb's third phase in Pengkalan Bujang spanned the eleventh to fourteenth centuries. His work on the Bujang Valley illustrated that the occupational sequences were longer and the cultural influences more complex than Quatritch Wales's assertions of Pallava colonisation.

Both Quaritch Wales and Lamb paid a great deal of attention to the architectural styles of the temples of the Bujang Valley. However, B. A. V. Peacock arguably made the most significant breakthrough in this regard. ${ }^{85}$ Focusing primarily on site 8 , he discussed Lamb's hypothetical reconstruction of site 8's central tower. ${ }^{86}$ Finding only a few lower courses during excavations, Lamb had tentatively proposed that it was a stone structure, more than 10 metres in height. ${ }^{87}$ However, Peacock pointed out that neither Lamb nor Quaritch Wales had uncovered large amounts of fallen masonry during their excavations throughout the Bujang Valley. Furthermore, with regard to the hypothetical central tower proposed by Lamb at site 8 , this debris should have been clearly visible. Another major objection was the positioning of stone pillar bases around the structure, clearly designed to support wooden pillars. Following Lamb's reconstruction, Peacock

${ }^{84}$ Alastair Lamb, 'Kedah and Takuapa: Some tentative historical conclusions', FMJ, VI (1961): $78-88$.

${ }^{85}$ B. A. V. Peacock, 'Pillar base architecture in ancient Kedah', JMBRAS, XLVII, 1 (1974): 6686.

${ }^{86}$ Ibid., pp. 70-3.

${ }^{87}$ Lamb, 'Report on the excavation', pp. 50-1. 
argued they would be architecturally defunct. ${ }^{88}$ The most damning evidence however, came from the foundations themselves which Peacock highlighted were not substantial enough to support the downward thrust of a large scale masonry superstructure.

Instead, Peacock proposed a tower with a wooden superstructure, consisting of multi-tiered roofs similar to those that can still be observed on Javanese buildings today. ${ }^{89}$ This type of structure fits much better with the surviving evidence not only from site 8 , but also from site 15 . The only question in Peacock's mind was the amount of tiers that made up the roof. Given that site 8 was dedicated to Siva, he speculates that it may have been eleven, the number ritually prescribed for this deity. Peacock's reconstruction answered a major architectural quandary faced by both Quaritch Wales and Lamb. In doing so, he too provided further weight to the arguments that the temples of the Bujang Valley were not imported wholesale from Pallava India, but instead represented adaptations of Indian models and forms by Southeast Asian artisans.

With the arrival of Malaysian independence in 1957, the old guard of British colonial archaeologists gradually gave way to a new generation of Malay scholarship. The most prominent Malaysian scholar was Nik Hassan Shuhaimi Nik Abd. Rahman (henceforth Nik Hassan). As well as undertaking excavations of sites in the Bujang Valley, Nik Hassan and the Muzium Negara (National Museum, Kuala Lumpur) carried out reconstructions of eight temples from 1972 until $1981 .^{90}$ These investigations and reconstructions led, in turn, to new finds,

\footnotetext{
${ }^{88}$ Peacock, 'Pillar base architecture', p. 72.

${ }^{89}$ Ibid., fig. 7.

90 They are sites 3, 5, 11, 16, 19, 21, 22 and 50. Sites 16, 21 and 50 were relocated after excavation and reconstructed in the direct vicinity of site 8 where the Lembah Bujang Archaeological Museum is now also located. While this created a small-scale archaeological park easily accessible to visitors, it distorts the archaeological landscape and context of these monuments. It creates the false impression that Bujang Valley sites were located on the slopes of the Gunung Jerai peak while, actually, apart from sites 8, 48, and 49, all the sites were located in the low-lying river valley. Apart from the cluster of temples consisting of nos. 19, 22 and 23, the
} 
particularly in terms of Buddhist sculpture. At sites 21 and 22 for instance, three terracotta Buddha images, one terracotta bodhisattava, a terracotta elephant, and a bronze bodhisattva were discovered. These finds allowed the researchers to propose a tenth to eleventh century date for the temple. ${ }^{91}$

While Quaritch Wales and Lamb had focussed their attention largely on the area of the Bujang River, in the 1980s Nik Hassan directed his efforts primarily to Sungai Mas/Sungai Muda. Owing to the construction of an irrigation canal that cut through the village of Sungai Mas, ceramic sherds, glass, and beads were uncovered. This led to surveys in the area by Nik Hassan and the National Museum in conjunction with Jane Allen. Six low mounds were investigated. ${ }^{92}$ Three of the most significant finds from these excavations were an inscribed stele depicting a stupa extremely reminiscent to the Buddhagupta stele discovered over 100 years earlier by James Low, ${ }^{93}$ a damaged Buddha head made from green shale stone, and a terracotta image of the goddess Hariti. ${ }^{94}$ They also discovered a votive tablet dated to the seventh century. In total, four excavations took place in the 1980s.

On the basis of his research throughout the 1970s and 80s, Nik Hassan gave a more refined occupational sequence for the Bujang Valley sites. As with Lamb, his conclusions refute Quaritch Wales's proposed chronology and also differ in certain instances from Lamb's. ${ }^{95} \mathrm{Nik}$

majority of Bujang Valley sites themselves are largely inaccessible today as many of them are on privately owned land, usually oil palm plantations.

${ }^{91}$ Nik Hassan and Othman, Antiquities, pp. 43-8.

${ }^{92}$ Ibid. pp. 8-9. This survey took place as part of Allen's PhD fieldwork.

${ }^{93}$ Jane Allen, 'An inscribed tablet from Kedah, Malaysia: Comparison with earlier finds', Asian Perspectives, XXVII, 1 (1986-87): 35-57; Jan Wisseman Christie, 'The Sanskrit Inscriptions recently discovered in Kedah, Malaysia', in Modern Quaternary Research in Southeast Asia, ed. Gert-Jan Bartstra \& Willem Arnold Casparie, vol. 11 (Rotterdam: A.A. Balkema, 1988-89), pp. $39-53$.

${ }^{94}$ Nik Hassan and Othman, Antiquities, p. 9.

${ }^{95}$ Ibid., pp. $90-4$. 
Hassan's most significant contribution was the confirmation that Sungai Mas was the pre-cursor to Pengkalan Bujang. His excavations show it was primarily Buddhist and that it was active from ca. the fifth to tenth centuries CE. The ceramic evidence from Tang and Song Dynasty China as well as the Persian wares indicate that during the seventh to ninth centuries it still functioned as a major entrepôt. By the end of the ninth or early tenth century, Nik Hassan agrees with Lamb's conclusion that Pengkalan Bujang became the more prominent entrepôt. He also sees the Buddhist phase ending around this time and giving way to Brahmanism, primarily Saivism, as is indicated by sites such as site no. 8 and those with vimana-mandapa ground plans. ${ }^{96}$

A systematic review of all fifty-two known archaeological sites as of 1991 was undertaken by Michel Jacq-Hergoualc'h. His publication provides plans and elevations for each temple as well as a list of finds. ${ }^{97}$ The majority of sites were constructed primarily of brick, but some, such as sites 16 and 50, were built of laterite, while site 8 was built of stone. Architectural features such as stone balustrades with makara designs have also been found to a limited extent; terracotta decorations such as elephants must have lined the facades of the temples.

Jacq-Hergoualc'h divides the structures into three groups, those which can be identified as Buddhist, those which are Brahmanical, and a third group for those which are unidentifiable or unexcavated. In total he lists nine Buddhist monuments, including both temples and stupas, 14 Brahmancial sites, and 17 unidentifiable or unexcavated. ${ }^{98}$ He classified the sites into either Buddhist or Brahmanical based on two criteria: associated finds and the architectural plan of the monument.

${ }^{96}$ Ibid., pp. 90-4; A mandapa is a pillared outdoor hall or pavilion used for public rituals. In the Bujang Valley examples they would have been constructed with wooden superstructures.

97 Jacq-Hergoualc'h, La civilisation.

98 The sites are: Buddhist; 1, 2, 10, 16A, 17, 21, 22, 37, 39. Brahmanical; 5, 6, 8, 11, 13, 14, 15, 16, 19, 24, 31, 49, 50. Unidentified/unexcavated; SMM 6, 7, 9, SMM 11, 12, 18, 20, 23, 25, 26, $28,32,33,35 / 36,38,40,48$, 
From his excavations Quaritch Wales noted that Brahmanical structures comprised of a single mandapa and vimana. In certain cases snana-droni, linga, and/or somasutras were found associated with the vimana (fig. 11). ${ }^{99}$ Buddhist sites consisted either of stupas or rectangular structures which may represent assembly halls sometimes referred to as vihara in literature on Southeast Asia. In an Indian context, on the other hand, vihara refers to the entire monastery.

Jacq-Hergoualc'h's conclusions differed somewhat from Quaritch Wales's and those proposed by others. He argued there were four areas that existed as entrepôts throughout the Bujang Valley's history: ${ }^{100}$ Kampong Sungai Mas, Pengkalan Bujang (in these first two he is in agreement with Nik Hassan), Kampong Simpor Tambang, and Kampong Sireh.

Kampong Simpor Tambang is located east of Sungai Mas on a tributary of the Sungai Terus known as the Sungai Simpor. The site is identified by the remains of a laterite wall. JacqHergoualc' $h$ argued that this was an entrepôt based on the large quantities of Chinese ceramics dating back to the tenth to thirteenth centuries, in addition to the beads and glass found there, as opposed to extensive remains of monuments. ${ }^{101}$ Allen, who first located the site, suggested it may have functioned as a relay site for Pengkalan Bujang. ${ }^{102}$

Kampong Sireh is located directly east of Kampong Sungai Mas on the Sungai Muda River. Again, the site was identified by the large quantities of ceramics, including Sawankhalok celadon sherds from Thailand dating to the fourteenth to fifteenth centuries, as well as Chinese and Middle East wares from the eleventh to twelfth. ${ }^{103}$ Due to the lack of archaeological research carried out at these two latter areas, their exact nature and functions are still uncertain. However, Jacq-Hergoualc'h's research highlighted that other areas were also involved in the trade network of the Bujang Valley.

\footnotetext{
${ }^{99}$ Some are today on display at the Lembah Bujang Archaeological Museum.

100 Jacq-Hergoualc'h, La civilisation, pp. 20, 30-1, fig. 2.

101 Jacq-Hergoualc'h, The Malay Peninsula, pp. 451-2.

102 Allen, 'Trade, Transportation and Tributaries', p. 369.

103 Jacq-Hergoualc'h, The Malay Peninsula, pp. 454-5.
} 
Jacq-Hergoualc'h's research also included a joint French-Malaysian excavation project of site 23 which resulted in the opening up of a larger area than had been done in the previous three field seasons, 1986-1988, under the supervision of Nik Hassan. ${ }^{104}$ The quadrangular structure of this monument, 11 x $9 \mathrm{~m}$, aligned southwest-northeast, was unlike others in the Bujang valley. Thus its religious orientation could not be clearly established. Finds of twelfth century Chinese celadons dated the site to this century.

Jacq-Hergoualc'h's work serves as an invaluable corpus of evidence indicating the extent and religious persuasion of the many extant monuments at the Bujang Valley. With this is mind, the paper now turns to the excavations carried out by the 2008 the Centre for Global Archaeological Research.

One of most interesting aspects of the new findings at the Sungai Batu site is the range of dates proposed by the excavators for the brick structure SB1B. Based on results of two OSL ${ }^{105}$ samples, they assessed the structure was 1800 -1900 years old, giving it a first to second century date. ${ }^{106}$ If correct, this would be the earliest Buddhist structure in Southeast Asia. ${ }^{107}$ Based on its architectural design, a round base surmounted by a square structure, it was most likely a stupa (fig. 12). Alternatively, it could be that a Hindu structure was built over a previously existing

\footnotetext{
104 Jacq-Hergoualc'h, La civilisation, pp. 167-73.

105 Optically Stimulated Luminescence (OSL) is a dating method employed by archaeologists to obtain a date when a mineral was last exposed to daylight. In the case of Sungai Batu this was conducted on fired brick samples. For more details on this technique see the free download summary provided by the Aberystwyth Luminescence Research Laboratory; http://www.aber.ac.uk/en/media/departmental/iges/pdf/english_heritage_luminescence_dating.pd $\underline{\mathrm{f}}$ 106 Zolkurnian Hassan et al. 'Survey and excavation', pp. 35-7. ${ }^{107}$ A certain amount of caution needs to be exercised with OSL dates. If the tested bricks were not fired at more than $400 \mathrm{C}$, an intrusion of the geological age of the clay can occur. Pers. comm. Janice Stargardt $3^{\text {rd }}$ Dec. 2014.
} 
stupa as this architectural form has no precedent anywhere in Southeast Asia. This identification is strengthened by the discovery of a very similar Buddhist stone inscription found by Quaritch Wales at site 1 . This inscription, however, is dated to the sixth to seventh centuries. ${ }^{108}$ Fingermarked bricks were also found, pointing towards Buddhism.

While the inscription was found in the upper layers of the excavation, its presence, coupled with the problem that no other Buddhist monument in Southeast Asia has been dated so early, raises concerns about the claims that this structure is datable to the first century. Prof. Saidin's has recently shared his interpretations about this issue. ${ }^{109} \mathrm{He}$ clarifies that the $2^{\text {nd }}$ century CE OSL dates come from the circular shaped base. However, on the top of the circular are square structures is another small round shaped structure. It is dated to the $6^{\text {th }}$ century CE and its form is clearly that of a stupa. That therefore leaves a difference of approximately 500 hundred years between the bottom 'stupa' structure and top one. It is this discrepancy that has led him to suggest that the round shaped form at the base dating to the second century may be an animistic monument related to rituals performed for Mount Jerai as it is too early a date for the presence of Buddhism or Hinduism.

Seen in this light, the context of Prof. Saidin's statement about the presence of animism becomes clear and his is seeking for an explanation for the early date. However, it may actually be a simple case of inaccurate OSL dates. One further OSL date from the jetty (SB1A) gave a date of 1740+/- 25 years BP, which would give a mid-third century date. Therefore, at present, we should be cautious of accepting the date of first to third centuries CE based on three OSL dates alone. Instead it would be more prudent to wait for the results of further research and testing. ${ }^{110}$. Excavations at the iron smelting site (SB2A) on the other hand produced a much more robust set of dates obtained from 22 samples using radiocarbon, AMS, and OSL dating. Tellingly they give

\footnotetext{
${ }^{108}$ Zolkurnian Hassan et al. "Survey and excavation", pp. 40-1.

${ }^{109}$ Email received by author $25^{\text {th }}$ July 2016.

${ }^{110}$ Statistically the sample SB1A and SB1B appears to be too small to rule out margins of error. Charles Higham et al. 'Cutting a Gordian Knot: the Bronze Age of Southeast Asia: origins, timing and impact', Antiquity, 85 (2011): 583-598, for instance, give an example from Mali where the OSL and radiocarbon dates differ by as much as 400 years.
} 
an occupational sequence of third to sixth centuries followed by a hiatus in human activity for about a century. The site is then active again from the seventh to sixteenth centuries. ${ }^{111}$

The research carried out at Sungai Batu has opened up a new chapter in our understanding of the Bujang Valley. It shows that this area was probably active in trading from ca. third century CE onward and possibly earlier. The jetty, site SB1A, and the iron smelting site, SB2A, provide particularly clear evidence in this regard. The large-scale production of iron gives some of the best evidence to date of what types of commodities were traded out of the Bujang Valley.

\section{The Bujang Valley: an extensive entrepôt complex}

An assessment of the research carried out to date on the Bujang Valley leads to one very clear conclusion: the area was not home to a "kingdom" or centre of an organised state, but was an extensive entrepôt complex that grew over numerous centuries and adapted and shifted its location over time to counter the effects of the silting of waterways and coastal progradation. A number of factors clearly support this view:

Firstly, Allen's work in particular shows that there was insufficient land to support large scale intensive wet rice farming, a necessary precondition for vertical state development such as at Angkor. ${ }^{112}$ The coastal plain that exists today was not present before ca. 1200 and could therefore not have been used in wet rice farming. ${ }^{113}$ Instead, the inhabitants employed intensive hill slope cultivation, which inevitably led to serious problems with erosion and subsequent

${ }^{111}$ Stephen Chia \& Naizatul Akma Mohd Mokhtar, 'Evidence of iron production at Sungai Batu, Kedah', in Bujang Valley and early civilisations in Southeast Asia, ed. Stephen Chia and Barbara Watson Andaya (Department of National Heritage, Ministry of Information, Communications and Culture, Malaysia, 2011), pp. 353-5.

112 Allen, 'Inland Angkor, Coastal Kedah', pp. 79-87.

113 Allen, 'In support of trade', p. 66. 
landform changes. ${ }^{114}$ Cultivation of hill slopes alone would not have produced sufficient agriculture yields to support a state-level society such as Angkor. ${ }^{115}$

Secondly, an inbuilt flexibility in Bujang Valley social structure resulting from changes in river flow and siltation meant that the entrepôt's centre or centres had built-in adaptive measures. As conditions became unfavourable in Sungai Batu, for example, the centre shifted to Sungai Mas, after which it moved to Pengkalan Bujang in the tenth to eleventh centuries.

Thirdly, the architectural remains of Bujang Valley are also telling. Over a period of $700-900$ years (ca. fifth to thirteenth centuries), temples remained essentially small-scale. This is in stark contrast to other Southeast Asian cultures such as Angkor in Cambodia, Bagan in Myanmar, or among the Cham of Vietnam, which over the timescale in question evolved ever more complex and grandiose architectural forms. Likewise in Java we see the creation of Borobudur in the eighth century and Prambanan in the ninth. Nothing coming close to this scale can be observed in the Bujang Valley.

Given its role as an entrepôt complex, it is likely that the temples in the Bujang Valley were sponsored by merchants and tradespeople, both foreign and indigenous. As fortunes, livelihoods, and the lives of the sailors were beholden on the vicissitudes of the oceans and seas, it is only natural that they would seek supernatural assistance to aid them in their endeavours. The Buddhagupta stele was dedicated by a sea captain as thanks for a safe passage. By the fifth century, the cult of Dipankara Buddha (the saviour of seafarers) had become understandably popular among merchants, while, from as early as the fourth century, worship of the bodhisattva Avalokitesvara began to incorporate beliefs that he could offer salvation from the seas. ${ }^{116}$

\footnotetext{
${ }^{114}$ Allen, 'Historical maps', pp. 146-7.

115 Allen 'Inland Angkor, Coastal Kedah', pp. 83-5.

116 John Guy, Lost Kingdoms: Hindu-Buddhist sculpture of early Southeast Asia, (New York:
} The Metropolitan Museum of Art, distributed by Yale University Press, New Haven and London, 2014), pp. 9-10. 
The placement and distribution of the temples in the Bujang Valley also support this viewpoint. Unlike other Southeast Asian examples where cities were carefully planned and their temples reflected microcosms of the Hindu and Buddhist universes, monumental architecture the Bujang Valley appears to have developed somewhat more organically. Arguments that the entrepôt went through distinctively Buddhist and Hindu phases are also misleading; it seems much more likely that both religions existed to greater or lesser extents throughout the centuries, the primacy or decline of either likely linked to shifting trade patterns and the religious affiliations of the merchants and traders plying these routes.

Due to its nature as an entrepôt complex, the Bujang Valley was also most likely quite cosmopolitan in character, which again would argue against clearly defined phases of religious affiliation. Comparison with Kollam in Southern India during the ninth century is informative. Kenneth Hall, in his analysis of copper plate inscriptions, shows that Kollam was an administered marketplace run by a Nestorian Christian within a kingdom ruled by a Hindu king. ${ }^{117}$ The inscriptions also mention four Jewish names, eleven Arabic names, and ten Persian names. In the Bujang Valley, we unfortunately do not have any such inscriptional evidence to rely on. However, if the travels of Yijing are anything to go by, then Chinese monks and therefore traders were transiting by at least the seventh century. ${ }^{118}$ The existence of Persian and Arab communities in China by the eighth century, ${ }^{119}$ paired with the ceramics, glass, and numismatic evidence found at Bujang Valley sites, strongly suggest that these ethnic groups, as

${ }^{117}$ Kenneth Hall, 'West coast 9th-century India maritime diaspora and the Indian ocean trade: the Sthanu Ravi Plates and the multi-dimensional Kollam port-of-trade community in the 9th century CE,' in Trading circuits, mobile cultures: Port-cities and littoral societies of the Indian Ocean, (Mumbai: K. R Cama Institute, forthcoming).

118 Yijing states that after Srivijaya he departed on a ship to India via Jietu. See Wade, 'Beyond the southern borders', p. 30.

119 John Guy, 'Rare and strange goods: International trade in ninth-century Asia', in Shipwrecked: Tang treasures and monsoon winds, ed. Regina Krahl, John Guy, J. Keith Wilson \& Julian Raby (Washington D.C.: Smithsonian Institution, 2010), pp. 20-1. 
well as Indians, were stopping here, waiting for both favourable monsoon winds and opportune business transactions.

The objects excavated by Quaritch Wales over seventy years ago should be viewed in the context of this extensive cosmopolitan entrepôt complex. For instance, the miniature shrine cover from site 4, which for Quaritch Wales spoke of Pallava colonisation, should be viewed as an object most likely brought to the site by a merchant or trader either of South Indian origin, or who had at least sojourned there for some time. Peacock's work on the architecture of the Bujang Valley sites strongly argues against the employment of any Mahabalipuram style roof structures. The stone tablet found at site 1 and those found recently at Sungai Batu seem to be part of a local tradition of carving the Ye Dharma formula on highly portable objects. Perhaps these were created by local Buddhist monks specifically for sailors who would take them to sea with them as talismans.

One ritual practice that both Buddhists and Hindus in Bujang shared was that of foundation deposits. The evidence from sites $8,10,13,14$, and 16 shows that this tradition spanned at least four to five centuries, from the eighth century at site 10 to the eleventh to twelfth centuries at site 8. Variation in terms of the reliquaries used and objects interred occurs, but the purpose appears consistent. As Ślączka pointed out, the ritual begins with purification of the ground and ends with an abhiseka (ablution) of the whole edifice. ${ }^{120}$ Both O'Connor and Ślączka have shown, contradicting Lamb's claim, that this practice is well documented in India. ${ }^{121}$ Therefore, it most likely arrived in the Bujang Valley as part of the overall set of rituals and ceremonies that the incoming Brahmins and Buddhists brought with them.

The Buddha from site 16A is another example of how Buddhism established itself within the Bujang Valley. The scholarly consensus is that it is of local manufacture, which suggests that there was a sufficiently large demand for religious paraphernalia to support local artisans.

\footnotetext{
120 Ślączka, 'Golden bulls', p.71.

${ }^{121}$ Ibid; O’ Connor, 'Ritual deposit boxes', pp. 53-60.
} 
However, there is some disagreement over the date. ${ }^{122}$ In the somewhat clumsy depiction of the robe on the back and sides, Guy sees a local artist struggling to master his subject matter and assigns a sixth century date. ${ }^{123}$ By comparison with sculpture from Nalanda, Heidi Tan interpretes this as artistic licence on the part of the sculptor and assigns it an eighth century date. $^{124}$

Dorothy Quaritch Wales did not assign a date to site 16A, though she did mention that the brick measurements do not suggest an early one. ${ }^{125}$ Furthermore, its location in Pengkalan Bujang pointed toward an eighth to ninth century date, or perhaps even tenth to eleventh. This raises two possibilities: the Buddha is of eighth to ninth centuries, as Tan proposed, or, alternatively, that the image is sixth century but was in use, presumably under worship at a shrine, for over two to three centuries. The latter explanation is by no means unlikely as many modern examples of religious icons in Southeast Asia have been worshipped over countless generations. In conclusion, it is difficult to say with certainty which period this Buddha image dates from.

\section{The Bujang Valley, Srivijaya, and its wider Southeast Asian context}

The Bujang Valley did not exist in isolation. On the contrary, it was a major entrepôt for most, if not all of its history. Since the 1930s, research has progressed significantly in terms of the ThaiMalay peninsula in general. Excavations, surveys, analysis of historical texts, and art historical studies of objects in museum collections have all contributed to advancing our understandings of the region and a clear picture emerges that Buddhism and Hinduism were present on the peninsula from the fifth century onwards. This section looks at the Bujang Valley within this wider geographic and historical context in light of the current research. It does so to reinforce the

\footnotetext{
122 Guy, Lost Kingdoms, cat. no. 20.

${ }^{123}$ Ibid., pp. 75-6.

${ }^{124}$ Heidi Tan, 'Examining Early Buddhist Materials from Srivijaya', in On the Nalanda Trail: Buddhism in India, China \& Southeast Asia, ed. Gauri Parimoo Krishnan (Singapore: Asian Civilisations Museum, 2008), pp. 84-5.

${ }^{125}$ Dorothy C. Quaritch Wales, \& Horace G. Quaritch Wales, 'Further work', p. 8.
} 
evidence already presented for the presence of Buddhism and Hinduism in this region as well as the interactions and connections it had with other entrepôts and polities on the peninsula.

\section{Srivijaya}

The early scholarship on Southeast Asia tended to see the Buddhist and Brahmanical civilisations that developed from the beginning of the first millennium onwards as kingdoms holding sway over clearly defined territories. ${ }^{126}$ These interpretations arose from both preconceived Western notions of how societies formed and evolved and also from the perceptions of these entities in ancient Chinese texts. Evidence for states such as Srivijaya, Dvaravati, Funan etc. had been gleaned from Chinese annals by sinologists such as Paul Pelliot at the start of the twentieth century. ${ }^{127}$ These texts spoke of Southeast Asian kingdoms and also assigned geographical boundaries to them. However, the Chinese writers compiled these descriptions filtered through their worldview, reflecting the political realities of their own society. It is understandable, therefore, that these early authors conceived these Southeast Asian polities as kingdoms along the lines of what Chinese versions described.

Understandings and interpretations of Srivijaya also fell prey to such assumptions. ${ }^{128}$ However, scholarship over the past forty years or so has largely debunked these overly neat "kingdoms" and, instead, now posits that they were much looser political entities than previously assumed. ${ }^{129}$ There is general consensus that the centre of Srivijaya was based in Palembang, South Sumatra, and rose to prominence between the seventh to ninth centuries. In the eleventh century, it was attacked and defeated in a maritime confrontation by the Cholas of South India, most likely in a

${ }^{126}$ See for instance George Coedès, The Indianized States of Southeast Asia, (Honolulu: University of Hawaii Press, 1968).

${ }^{127}$ See for example, Paul Pelliot, 'Le Fou-nan', BEFEO III, (1903): 248-303; Paul Pelliot, 'Deux itinératires de Chine en Inde à la fin du VIII ${ }^{\mathrm{e}}$ siècle', BEFEO IV, (1904): 131-413. ${ }^{128}$ George Coedès, 'Le royuame de Çrīvijaya', BEFEO XVIII, 6 (1918): 1-36. ${ }^{129}$ Oliver Wolters, Early Indonesian Commerce: A Study of the Origins of Śrivijaya (Ithaca: Cornell University Press, 1967). 
battle for control of the sea lanes. ${ }^{130}$ Towards the end of the eleventh century, the locus of power shifted north to Jambi. ${ }^{131}$ Srivijaya's location at Palembang has been established by excavations conducted there over the past thirty plus years as part of a Franco-Indonesian research program initiated in the 1980s. ${ }^{132}$ Srivijaya is also now understood not to be a maritime empire controlling vast swathes of sea and coastlines, but instead a network of port-cities and entrepôts. Palembang most likely exacted a certain amount of control over ports as far north as Chaiya in southern Thailand and, at times, as far south as West Java, most likely extracting tribute or a form of taxation on trade. ${ }^{133}$ Palembang may also have extended its control through a system of alliances. Hermann Kulke argues, on the basis of his analysis of inscriptions, that there were several centres of political authority based around the royal palace and, similar to O. W. Wolters, sees a mandala structure where influence spread out from the centres (viz. Palembang) in concentric circles. $^{134}$

O’Connor envisioned Srivijaya as an alliance of harbour principalities with a leader based at Palembang, which may have functioned in a similar fashion to the Hanseatic League in the North

130 Jacq-Hergoualc'h, The Malay Peninsula, pp. 355-7.

${ }^{131}$ Pierre-Yves Manguin, 'The Archaeology of the early maritime polities of Southeast Asia', In Southeast Asia: from prehistory to history, ed. Peter Bellwood \& Ian C. Glover (London: Routledge Curzon, 2004), p. 306.

132 Ibid., pp. 306-7.

${ }^{133}$ Pierre-Yves Manguin and Agustijanto Indradjaja, 'The Batujaya Site: New Evidence of Early Indian Influence in West Java', in Early Interactions between South and Southeast Asia: reflections on cross-cultural exchange, ed. Pierre-Yves Manguin, A. Mani and Geoff Wade (Nalanda-Sriwijaya Series 2. Singapore: Institute of Southeast Asian Studies, 2011), pp. 113-4. ${ }^{134}$ Hermann Kulke, 'Kadatuan Srivijaya - empire or kraton of Srivijaya? A reassessment of epigraphical evidence', BEFEO 80, (1993):159-81; Oliver Wolters, History, Culture, and Region in Southeast Asian Perspectives (Ithaca: Southeast Asia Program, Cornell University, 1999). 
and Baltic Seas. ${ }^{135}$ Leonard Andaya points out that it would be extremely difficult for any one leader to exert direct control over any of the coastal polities, as the inhabitants could easily flee inland into the mountains or to any of the surrounding islands. Therefore, a large and permanent military force would be needed to maintain a grip. ${ }^{136}$ Thus, it seems most likely that Srivijaya was a polycentric trading network built around a system of alliances and tribute.

Given the Bujang Valley's prominence as a major entrepôt complex along the west coast of the Thai-Malay peninsula, it was most certainly part of the Srivijaya network. The ceramic assemblages found throughout the area, as well as the glass, beads, and Buddhist and Brahmanical imagery and paraphernalia, illustrate that the Bujang Valley was an active participant in the trade flows between India and China and within Southeast Asia as well. Tansen Sen, building on the work of scholars such as K. N. Chaudhuri, points out that there were interlocking circuits of trade in existence. ${ }^{137}$ Southeast Asia interacted independently with both China and India but was also part of their overlapping trade networks. Furthermore, regional Southeast Asian trade networks would also have existed, with, once again, the Bujang Valley being a key entrepôt. Some of these potential regional networks on the peninsula are now discussed.

\section{The Kinta Valley}

While the majority of studies in peninsular Malaysia have focused on the Bujang Valley, a number of other significant finds have been discovered on the peninsula, particularly along the course of the Kinta Valley in Perak. This river system is some 200 kilometres south of Bujang and was the find spot for a number of bronze Buddha and bodhisattva images. For instance, an

${ }^{135}$ Cited in Wannasarn Noonsuk, Tambralinga and Nakhon Si Thammarat: Early kingdoms on the isthmus of Southeast Asia (Nakhon Si Thammarat: Nakhon Si Thammarat Rajabhat University, 2013), pp. 183-4.

${ }^{136}$ Leonard Andaya, Leaves of the same tree: Trade and ethnicity in the straits of Melaka (Honolulu: University of Hawaii Press, 2008), p. 62.

${ }^{137}$ Tansen Sen, 'Maritime Southeast Asia between South Asia and China to the sixteenth century', TRaNS: Trans-Regional and -National Studies of Southeast Asia, 2, 1 (2014): 32-4. 
eight-armed bodhisattva found in 1908 near Bidor is one of the finest Avalokitesvara images ever found in Southeast Asia. ${ }^{138}$ Another bodhisattva, as well as a Buddha image, both dating to the sixth to ninth centuries, were also found within the valley and attest to the presence of this religion in the area. ${ }^{139}$ However, no archaeological settlements have been found within this river valley to date, making it difficult to pinpoint where these pieces may have been produced. The high level of skill required to cast images of this quality indicate that highly trained artisans did operate in the region by this period. Perhaps they moved between this valley and Bujang, offering their skills to potential clients, suggesting a trade or crafts circuit. The discovery at Bujang Valley site 10 of gold and silver disks inscribed with names of bodhisattvas, as well as the contents of the bronze reliquary from site 16, which may represent a tantric form of the deity, point towards both the Bujang and Kinta valleys sharing common religious orientations during the sixth to ninth centuries.

\section{Thung Tuk, Khuan Luk Pad, and Khao Nui}

In recent years the Thai Fine Arts Department (henceforth FAD) has conducted a number of excavations along the west coast of the peninsula. They include Khao Nui in Trang province and Thung Tuk at the mouth of the Takuapa River, Phang Nga province, approximately 370 and 450 kilometres north of the Bujang Valley, respectively (fig. 1). The site of Thung Tuk, which Quaritch Wales himself visited in 1935, shares many similarities with the Bujang Valley, albeit on a smaller scale. Furthermore, at the site of Khao Phra Narai some $15 \mathrm{~km}$ or so to the south of Thung Tuk, an over life-size Vishnu image as well as two fragmentary images of the Pallava period were discovered. At another site, Khao Phra Noe, just across the river from Thung Tuk, a monumental Vishnu image of the eighth to ninth centuries had been found. ${ }^{140}$

\footnotetext{
138 John Guy, Lost Kingdoms, cat. no. 157.

${ }^{139}$ Nik Hassan Shuhaimi bin Nik Abd. Rahman (ed.), The Encyclopedia of Malaysia: Early History (Singapore: Archipelago Press, 1998), p. 108.

140 Jacq-Hergoualc'h, The Malay Peninsula, pp. 124-5, 328-31.
} 
Excavations carried out by the FAD at Thung Tuk in 2003 uncovered eight brick structures averaging $8 \times 6$ metres in size. ${ }^{141}$ Stone pedestals found at Thung Tuk site 2 show similarities with those found in the Bujang Valley as do a number of terracotta roof tiles. These may indicate that these structures had wooden superstructures. ${ }^{142}$ Chinese ceramics such as Yue and Changsha wares found at the site date it between the eighth to tenth centuries, as do turquoise-glazed Persian ware. ${ }^{143}$ It appears, therefore, that Thung Tuk has a shorter lifespan than the Bujang Valley with its existence most likely due in part to its location as a nodal point for a transpeninsular route to the Bay of Bandon and Chaiya on the east coast.

One hundred and fifty kilometres to the south, the site of Khuan Luk Pad in Krabi province has turned up evidence of trade in the form of the numerous glass beads. Further south again, the FAD recently excavated the cave site of Khao Nui in Trang province where over 400 Buddhist votive tablets of the seventh to ninth centuries were discovered. ${ }^{144}$ Most bore bodhisattva, stupa, and Buddha images respectively, with the excavators classifying the votive tablets into eight types. This new discovery adds to our knowledge of a number of other cave sites in the region, such as Khao Ok Thalu and Khuha Sawon in Phattalung province, Khao Chum Thong in Nakhon Si Thammarat province, as well as Wat Ham and Wat Phra Phut in Trang, most in relatively

${ }^{141}$ Boonyarit Chaisuwan \& Rarai Naiyawat, Thung Tuk: A settlement linking together the maritime silk route (Thailand: Fine Arts Department, 2009), p. 42-3.

142 Ibid., p. 52.

${ }^{143}$ Ibid., pp. 71-6.

144 ภาณุวัฒน์ เอื้อสามาลย์ [Phanuwat Nuwat], 'การกำหนดอายุสมัยแหล่งพระพิมพ์ดินดิบเขานุ้ย จังหวัดตรัง ใน การประชุมวิชาการความก้าวหน้าทางวิชาการ โบราณคดีและการจัดการทรัพยากรทางวัฒนธรรมของชาติ 3-4 มีนาคม 2557 (วิชาการโบราณคดี คณะโบราณคดี มหาวิทยาลัยสิลปากร กรมสิลปากร, 2557) ['kankamnotayu samai lae lang phraphim dinphao khao niu changwat trang', nai Kanprachumwichakan khwamkaona thang wichakan kanchatkan sapyakon thang watthanatum kong chat] (Bangkok: Department of Archaeology, Silpakorn University, 2014), pp. 159-73. 
close proximity to one another. ${ }^{145}$ The volume of votive tablets found at these sites illustrates the extent to which Mahayana Buddhism had taken hold along this strip of the peninsula.

The sites of Thung Tuk, Khuan Luk Pad, and Khao Nui most likely owe their existence to their locations as nodes on the transpeninsular routes to the Bay of Bandon and also Tambralinga (see below). ${ }^{146}$ However, while these sites flourished particularly between the seventh and tenth centuries, the Bujang Valley appears to have remained the major entrepôt complex on the west coast of the peninsula; these smaller sites possibly acted as stopping off points for ships hugging the coast on their way up or down the peninsula. The similarity in ceramic assemblages from the Tang period found at both Bujang and Thung Tuk as well as some glass fragments clearly indicate they were part of the same trade network. ${ }^{147}$

\section{Tambralinga, Satingphra, and Langkasuka}

While the Bujang Valley entrepôt complex was the dominant port of call on the west coast of the peninsula, on the east coast a number of other major polities existed by the fifth to sixth centuries onwards. Most prominent amongst these were Tambralinga, Satingphra, and Langkasuka, all located with good access to both the Gulf of Thailand and the South China Sea as well as the transpeninsular routes to the Andaman Sea.

Tambralinga was located at what is today the modern city of Nakhon Si Thammarat and came into existence as a major coastal polity from the fifth century onwards. ${ }^{148}$ Its religious persuasion was primarily Brahmanical, but Buddhism was also present. There is evidence for both Vaisnaivism and Saivism, the former evidenced by a group of Vishnu images discovered in the

145 Pattaratorn Chirapravati, Votive Tablets in Thailand, Origin, Styles and Uses (Kuala Lumpur: Oxford University Press, 1997), pp. 33-9.

${ }^{146}$ See Jacq-Hergoualc'h, The Malay Peninsula, fig. 8.

147 Alastair Lamb, 'The bases of glass vessels from Kedah and Takuapa compared', FMJ, VI (1961): 58-60.

${ }^{148}$ Noonsuk, Tambralinga, p. 57 
area dating from the ca. fifth to seventh centuries. ${ }^{149}$ Saivism is represented in the form of linga, also found within what are understood to be the limits of the Tambralinga polity. ${ }^{150}$ At the site of Khao Kha, Noonsuk has argued that two examples of linga are carved out of the natural rock. ${ }^{151}$ Noonsuk proposed a chronology for Tambralinga as follows: an early Period (fifth to eleventh centuries), a late period (twelve to fourteenth centuries), and the Ayutthaya period (fifteenth to eighteenth centuries). Tambralinga was an active coastal city for much of the same period as the Bujang Valley and both came under the port trading system of Srivijaya from circa the seventh century. ${ }^{152}$ They also display some architectural similarities in the construction of their monuments.

At Khao Kha, in Sichon province, stone bases for pillars were found at many of the brick Brahmanical temples. Furthermore, as with sites at the Bujang Valley, the doorjambs and thresholds were made of stone. Just like the Bujang Valley and at Thung Tuk, a wooden superstructure was the favoured architectural form, supplemented by stone thresholds and doorjambs in certain cases. Transpeninsular routes clearly connected these two ports, perhaps via

${ }^{149}$ These were originally investigated by Stanley O'Connor, Hindu Gods of Peninsular Siam (Supplementum XXVIII. Ascona: Artibus Asiae, 1972) and more recently by Paul Lavy, 'As in Heaven, so on Earth: The politics of Viṣnu, Śiva and Harihara images in Preangkorian Khmer Civilisation', Journal of Southeast Asian Studies, 34, 1 (2003): 21-39; Paul Lavy, 'Conch-on-hip images in Peninsular Thailand and early Vaisnava Sculpture in Southeast Asia', in Before Siam: Essays in Art and Archaeology, ed. Nicolas Revire and Stephen A. Murphy (Bangkok: The Siam Society and River Books, 2014), pp. 152-73 and Noonsuk, Tambralinga, pp. 74-97.

${ }^{150}$ Noonsuk, Tambralinga, p. 103

${ }^{151}$ Ibid., pp. 115-7, figs. 3.6 and 3.7.

${ }^{152}$ For Tambralinga, this is reflected by the so called Ligor inscription. See Jacq-Hergoualc'h, The Malay Peninsula, pp. 242-7. 
Sating Phra on the east coast. ${ }^{153}$ Both Bujang and Tambralinga would have functioned as vital nodes on the international trade routes.

Excavations at the site of Sating Phra, 120 kilometres south of Tambralinga, have produced evidence for tradewares stretching from ca. the second to fourteenth centuries. ${ }^{154}$ It has been proposed by Stargardt that this site became a major urban centre from the sixth century onwards supported by wet rice cultivation. ${ }^{155}$ Allen sees the peak period of activity for the site at between the eighth to fourteenth centuries, and that the site location was chosen due to its suitability as a port, its access to the mountains for obtaining tradable forest products, and its position as a node on the transpenisular routes. ${ }^{156}$

The closest coastal port-city to the Bujang Valley is Langkasuka, located in what is today Pattani province of Thailand. ${ }^{157}$ As the crow flies it is about $160 \mathrm{~km}$ northeast of the Bujang Valley. Of particular interest is the site of Yarang, also known as the Yarang Archaeological complex, which dates to the sixth to ninth centuries and is considered the possible center of Langkasuka. ${ }^{158}$ Its inhabitants are thought to have been primarily Buddhist, although lingas have also been found here. Ten kilometres north of Yarang, the site of Ban Bana is primarily Brahmanical. ${ }^{159}$ These

${ }^{153}$ For instance fragments of a kendi pot in the NHB collection excavated by Quaritch Wales from the Bujang Valley and examined by the author and Prof. John Miksic are of a type known to be manufactured at Nakhon Si Thammarat.

154 Janice Stargardt, Satingpra 1: The environmental and economic archaeology of South Thailand (British Archaeological Reports International Series 158, 1983), pp. 24, 32.

155 Ibid.

156 Allen, 'In support of Trade', p. 70.

157 Jacq-Hergoualc'h, The Malay Peninsula, pp. 161-2

158 Wannasarn Noonsuk, 'New evidence of early Brahmanical vestiges in Pattani province', in Before Siam: Essays in Art and Archaeology, ed. Nicolas Revire and Stephen A. Murphy (Bangkok: The Siam Society and River Books, 2014), pp. 177-9. 159 Ibid., pp. 180-1. 
sites warrant further investigation as their locations suggest that they were on a direct transpeninsular route connecting them with the Bujang Valley. ${ }^{160}$

By looking at the wider context of the Thai-Malay peninsula it becomes apparent that the Bujang Valley was part of a system of flourishing trade-based societies and economies operating on both coasts. During certain periods these sites would have come within the orbit of Srivijaya; therefore, international and regional trade and commerce would then have been monopolised by Palembang. However, at other times, particularly from the eleventh to thirteenth centuries when Srivijaya's power waned, the Bujang Valley and sites such as Tambralinga and Langkasuka most likely enjoyed greater autonomy. While much research has been done on these individual sites, the connections between them have not been investigated to any significant degree and may prove to be a very valuable topic of future study.

\section{Conclusion}

In the over a century and a half since James Low made his first discoveries in Kedah, our knowledge and understanding of the significance of the Bujang Valley has increased considerably. The excavations of Quaritch Wales represented the first attempt to understand the entrepôt. While his pre-conceived notions about Hindu-Pallava colonists can today be dismissed, his work set in motion the almost continuous archaeological research that has taken place until today. As a result, we now know that this river valley represented the most extensive entrepôt complex on the west coast of the Thai-Malay peninsula for almost a millennium, from the early centuries CE until it was finally supplanted by Melaka in the fourteenth century. Furthermore, it did not exist in isolation, but was part of a web of maritime and transpeninsular trade routes, which linked it not only to sites on the east coast of the peninsula but also to cities and civilisations much further afield. Chinese ceramics, Persian pottery, Arab glass, and Indian religions reflect that the Bujang Valley was a cosmopolitan centre at the heart of maritime trade,

${ }^{160}$ Due to the unstable political situation in Pattani province at present, fieldwork is not possible. See Noonsuk 'New evidence,' p. 175. For the transpeninsula route see, ibid., map 1. 
located as it was on a key pivot of the route between East and West. In closing, the Bujang Valley should be celebrated as a reflection of Malaysia's cosmopolitan and multicultural history. 